\title{
ANALISIS UMUR REKSADANA, EXPENSE RATIO DAN KINERJA REKSADANA SAHAM DI PERUSAHAAN MANDIRI INVESTASI PERIODE 2014-2019
}

\author{
Muhammad Helmi ${ }^{1}$, Jumali ${ }^{2}$ \\ Sekolah Tinggi Ilmu Ekonomi Mulia Darma Pratama Palembang \\ E-mail:hm.helmi@gmail.com¹, jumali474@gmail.com²
}

\begin{abstract}
Abstrak
Reksadana adalah sarana investasi yang dipergunakan untuk menghimpun dana dari masyarakat pemodal untuk selanjutnya di investasikan dalam portofolio efek oleh manajer investasi, dan selanjutnya akan di investasikan pada saham, obligasi, deposito berjangka, pasar uang, dan lain sebagainya. Kinerja reksadana dipengaruhi oleh faktor penentu apakah reksadana berkinerja baik atau buruk, faktor kinerja reksadana yakni yang pertama adalah usia/ umur reksadana (Fund Age), yang kedua yakni perbandingan antara biaya operasi dalam satu tahun dengan rata-rata nilai aset bersih dalam satu tahun (Expense Ratio) dan yang ketiga Nilai Aktiva Bersih (NAB). Rumusan masalah dalam penelitian ini yaitu (1) Bagaimana perkembangan umur reksadana saham pada perusahaan Mandiri Investasi periode 2014-2019? (2) Bagaimana perkembangan expense ratio reksadana saham pada perusahaan Mandiri Investasi periode 2014-2019? dan (3) Bagaimana perkembangan nilai aktiva bersih (NAB) kinerja reksadana saham pada perusahaan Mandiri Investasi periode 2014-2019?. Penelitian ini bertujuan untuk mengetahui perkembangan umur reksadana, expense ratio dan nilai aktiva bersih (NAB) kinerja reksadana saham Mandiri Investa Atraktif (MITRA) diperusahaan Mandiri Investasi periode 2014-2019. Objek yang diteliti pada penelitian ini yaitu variabel yang berupa umur reksadana, expense ratio, dan kinerja reksadana (NAB). Metode analisis data dalam penelitian ini menggunakan metode analisis Deskriptif. Hasil dari penelitian yang dilakukan adalah perkembangan umur reksadana saham Mandiri Investa Atraktf (MITRA) pada perusahaan Mandiri Investasi mengalami kenaikan usia pada tahun 2014-2019. Perkembangan expense ratio pada tahun 2014-2019 mengalami penurunan. Dan pada perkembangan kinerja reksadana saham yakni nilai aktiva bersih (NAB) ditahun 2014-2019 mengalami fluktuasi.
\end{abstract}

Kata kunci: Umur Reksadana, Expense Ratio, Kinerja Reksadana Saham

\begin{abstract}
Abstrack
Mutual funds are investment facilities that are used to raise funds from the investor community for further investment in securities portfolios by investment managers, and subsequently invested in stocks, bonds, time deposits, money market, and so on. Mutual fund performance is influenced by the determining factors of whether a mutual fund performs well or poorly, the mutual fund performance factor, namely the first is the age / age of the mutual fund (Fund Age), the second is the comparison between operating costs in one year and the average net asset value in one year (Expense Ratio) and the third is Net Asset Value (NAV). The formulation of the problems in this research are (1) How is the development of the age of equity funds in Mandiri Investasi for the 2014-2019 period? (2) How is the development of the stock mutual fund expense ratio at the Mandiri Investasi period of 2014-2019? net assets (NAV) of equity mutual funds performance at Mandiri Investasi for the 2014-2019 period. This study aims to determine the development of mutual funds age, expense ratio and net asset value (NAV) of the performance of Mandiri Investa Attractive (MITRA) equity funds in Mandiri Investasi for the period 2014-2019. The objects examined in this study are variables in the form of mutual funds age, expense ratio, and mutual fund performance (NAV). Methods of data analysis in this study using descriptive analysis methods. The results of the research conducted were the age development of Mandiri Investa Attraktf (MITRA) equity funds at the Mandiri Investasi company, which experienced an increase in age in 2014-2019. Expense ratio development in 2014-2019 has decreased. And in the development of equity mutual funds performance, namely the net asset value (NAV) in 2014-2019 experienced fluctuations.
\end{abstract}

Keywords: Mutual Fund Age, Expense Ratio, Equity Mutual Fund Performance 


\section{PENDAHULUAN}

Seiring meningkatnya kebutuhan manusia membuat setiap orang memikirkan masa depan mereka. Peningkatan kebutuhan tersebut tentunya haruslah di imbangi dengan peningkatan penghasilan, namun sebaliknya seringkali hal tersebut tidak sejalan dengan penghasilan yang diperoleh. Mempersiapkan keuntungan dimasa mendatang menandakan adanya persiapan dan strategi, untuk menjalani kehidupan yang lebih baik dimasa mendatang. Kondisi inilah yang mendorong orang untuk menyisihkan sebagian dari pendapatan mereka dalam suatu wadah yang diharapkan akan meningkatkan nilainya dimasa mendatang yang disebut dengan investasi. Kesadaran akan pentingnya investasi membuat seseorang mengambil langkah nyata untuk berinvestasi pada salah satu instrumen investasi yang sesuai dengan dirinya. Hal tersebut merupakan suatu tindakan positif yang dilakukan seseorang untuk mencapai kehidupan yang lebih baik dimasa mendatang.

Menurut Fahmi (2018:2) investasi pada hakikatnya merupakan penempatan sejumlah dana pada saat ini dengan harapan untuk memperoleh keuntungan dimasa mendatang.

Menurut Fahmi (2018:2) PSAK nomor 13 dalam standar akuntansi keuangan 1 Oktober 20014, investasi adalah suatu aset yang digunakan perusahaan untuk pertumbuhan kekayaan (accretion of wealth) melalui distribusi hasil investasi (seperti bunga, royaliti, dan uang sewa), untuk apresiasi nilai investasi, atau manfaat lain bagi perusahaan yang berinvestasi seperti manfaat yang diperoleh melalui hubungan perdagangan. Dengan demikian, investasi dapat di definisikan sebagai bentuk pengeloalaan dana guna memberikan keuntungan dengan cara menempatkan dana tersebut pada alokasi yang diperkirakan akan menambahkan keuntungan.

Menurut Fahmi (2009:7) jenis investasi pada umumnya dikenal ada dua bentuk yaitu, investasi nyata (real investment) adalah secara umum melibatkan aset berwujud, seperti tanah mesin-mesin atau pabrik. Investasi ini relatif lebih sulit untuk dicairkan karena terbentur pada komitmen jangka panjang antara investor dengan perusahaan. Investasi keuangan (financial investment) adalah secara umum melibatkan aset kontrak tertulis, seperti saham biasa (common stock) dan obligasi (bond). Investasi ini lebih mudah dicairkan karena dapat diperjual belikan tanpa terikat waktu. Dari 2 jenis analisis investasi tersebut maka dalam penelitian ini hanya berfokus pada satu jenis investasi saja yakni investasi keuangan (financial investment).

Menurut Mudjiyono (2012) jenis investasi keuangan/ instrumen (Financial Investment) yang terdapat di pasar modal yaitu: Saham, Obligasi dan Reksadana. Pada penelitian ini menggunakan salah satu jenis investasi yaitu reksadana.

Menurut Lidyah (2017) reksadana menurut UU No. 8 tahun 1995 pasal 1 ayat $27 \mathrm{di}$ definisikan sebagai wadah yang dipergunakan untuk menghimpun dana dari masyarakat pemodal untuk selanjutnya di investasikan dalam portofolio efek oleh manajer investasi. Berdasarkan definisi tersebut, secara jelas bahwa reksadana merupakan kumpulan dana-dana dari masyarakat yang di investasikan pada saham, obligasi, deposito berjangka, pasar uang, dan lain sebagainya.

Menurut Desiyanti (2014) alasan investor memilih reksadana adalah kinerjanya, reksadana merupakan salah satu alternatif investasi bagi investor kecil atau investor yang tidak banyak memiliki waktu dan kemampuan untuk menghitung risiko atas investasi yang dilakukan. Reksadana memerlukan modal yang sedikit dan sangat cocok untuk dipilih oleh para pemodal atau pemula yang tidak ingin dipersulit dengan analisa pasar yang rumit. Selain itu juga reksadana merupakan jenis investasi yang aman karena sudah diawasi oleh Otorasi Jasa Keuangan (OJK) sehingga uang akan di jamin aman dan tidak hilang. Reksadana akan dikelola oleh perusahaan yang berperan sebagai manajer investasi, manajer investasi inilah yang akan mengelola dana yang telah di investasikan pada produk investasi, seperti pasar uang, obligasi, saham, atau deposito.

Menurut Meilinda (2010) manfaat berinvestasi di reksadana adalah dikelola oleh Manajer Investasi (Ml) yang professional, transparan, secara rutin Ml meyampaikan laporan keuangan, fleksibel, murah/ terjangkau, sangat likuid, terdiversifikasi secara otomatis, kemudahan dalam alokasi aset, fasilitas pajak, aman dan diatur lebih ketat karena peraturan yang berlaku di pasar modal akan berlaku bagi reksadana pula, bisa memenuhi banyak kebutuhan investasi karena keragaman jenis dan perbedaan perbedaan reksadana yang 
ditawarkan kepada investor untuk mencapai banyak tujuan investasi dan time horizon.

Menurut Lidyah (2017) jenis-jenis reksadana dibagi menjadi empat jenis reksadana yaitu, reksadana pasar uang, reksadana pendapatan tetap, reksadana saham, dan reksadana campuran. Dalam penelitian ini menggunakan variabel reksadana saham.

Menurut Asriwahyuni (2017) penilaian terhadap kinerja reksadana penting untuk dilakukan karena dengan melakukan penelitian terhadap kinerja reksadana saham dapat diketahui kemampuan reksadana untuk bersaing dengan reksadana lain dipasar serta mengetahui kemampuan reksadana dalam menghasilkan keuntungan (return). Return dari reksadana dikenal dengan nilai aktiva bersih (NAB) dimana nilainya akan diperbaharui setiap hari berdasarkan hasil transaksi reksadana pada hari tersebut.

Menurut Bitomo (2016) kinerja reksadana dipengaruhi oleh banyak faktor penentu apakah reksadana berkinerja baik atau buruk. Faktor-faktor kinerja reksadana yakni yang pertama adalah kinerja masa lalu (Past Performance), yang kedua yaitu ukuran reksadana (Fund Size), yang ketiga usia/ umur reksadana (Fund Age), yang keempat yakni perbandingan antara biaya operasi dalam satu tahun dengan rata-rata nilai aset bersih dalam satu tahun (Expense Ratio). Dan faktor lainnya seperti kinerja reksadana yakni arus kas reksadana (Fund Cash Flow) dan Nilai Aktiva Bersih (NAB).

Untuk menentukan analisis reksadana saham di dalam penelitian ini, maka analisis yang digunakan dalam penelitian ini yakni umur reksadana, expense ratio dan nilai aktiva bersih (NAB).

Umur reksadana (fund age), menurut Akbarini (2004) umur reksadana (fund age) merupakan kategori yang berjenis numerik, dimana ia menunjukkan usia dari tiap reksadana yang dihitung sejak tanggal reksadana tersebut efektif diperdagangkan.

Menurut Rao (2000) banyak investor yang lebih menyukai reksadana yang berumur lebih lama. Reksadana yang memiliki umur lebih lama akan memiliki track record yang lebih panjang, maka dari itu akan dapat memberikan gambaran kinerja yang lebih baik kepada investornya. Asumsi ada yang menyatakan bahwa semakin tua umur reksadana maka ia akan berkinerja lebih baik, karena manajer investasinya sudah berpengalaman di bandingkan dengan yang berusia muda, dengan umur reksadana yang lebih muda mungkin akan menghadap pada biaya yang lebih tinggi pada periode awal.

Penelitian terdahulu yang dilakukan oleh Saurahman (2015) yang menyatakan bahwa adanya pengaruh positif dari umur reksadana terhadap kinerja reksadana. Penelitian yang dilakukan oleh Blacke dan Timmerman (1998) memberikan bukti langsung bahwa ada hubungan positif antara usia dan kinerja reksadana, ini menunjukkan adanya pengalaman ekonomi.

Menurut Bitomo (2016) expense ratio adalah perbandingan biaya operasional reksadana dengan total dana yang dikelola atau perbandingan antara biaya operasi dalam satu tahun dengan rata-rata nilai aset bersih dalam satu tahun. Dalam hal ini data expense ratio diperoleh dari prospektus yang dipublikasi masing-masing reksadana atau jika didalam prospektus tidak dicantumkan data expense ratio maka dapat diperoleh dengan melihat laporan keuangan masing-masing reksadana. Dalam laporan keuangan reksadana, expense ratio telah dicantumkan sebagai ikhtisar keuangan. Adapun tolak ukur dalam perhitungan expense ratio dengan menggunakan total biaya reksadana, aktiva bersih reksadana dan jumlah periode waktu nya.

Dalam penelitian terdahulu menurut See dan Jusoh dalam Kurniadi (2014) Expense ratio berpengaruh signifikan terhadap kinerja reksadana. Menurut Lidyah (2017) expense ratio merupakan total biaya yang dikeluarkan untuk kegiatan operasional perusahaan yang meliputi biaya administrasi dan manajemen untuk menunjang operasional reksadana.

Definisi nilai aktiva bersih (NAB) menurut Iman (2008:128) NAB merupakan nilai pasar wajar (fair market value) suatu efek dan kekayaan lain dari reksadana dikurangi dengan kewajiban (utang). NAB merupakan salah satu tolak ukur dalam memantau hasil dari suatu reksadana. Nilai aktiva bersih per unit penyertaan adalah harga wajar dari portofolio suatu reksadana setelah dikurangi biaya operasional kemudian dibagi jumlah saham/ unit penyertaan yang telah beredar (dimiliki investor) pada saat tersebut.

Menurut Usman (2000:74) nilai aktiva bersih (NAB) tidak bisa dipisahkan dari reksadana, karena istilah ini merupakan salah 
satu tolak ukur dalam memantau hasil dari suatu reksadana. Pengertian NAB adalah total market value dari suatu portofolio dikurangi kewajibannya, dibagi dengan total jumlah saham yang beredar. Yang dimaksud dengan NAB adalah sejumlah aktiva setelah dikurangi kewajiban-kewajiban yang ada. Sedangkan NAB persaham atau perunit penyertaan adalah harga wajar dari portofolio suatu reksadana setelah dikurangi semua biaya operasional (kewajiban) dan dibagi dengan jumlah saham atau unit penyertaan yang beredar (dimiliki investor) pada saat tersebut.

Manfaat/ kegunaan dari nilai aktiva bersih (NAB) adalah dasar untuk menghitung harga unit investasi dalam reksadana atau yang disebut dengan NAB/UP. Untuk mencari tahu harga dari unit sebuah investasi dari perusahan reksadana, tinggal lihat saja data NAB/UP dari perusahana bersangkutan. Nilai NAB/UP berubah setiap harinya karena didasarkan pada penghitungan NPW (Nilai Pasar Wajar) yang berlaku. Faktor lain yang mempengaruhi perubahan NAB/UP adalah perubahan dana yang dikelola oleh MI atau Asset Under Management (AUM) mengalami peningkatan nilai.

Pada penelitian sebelumnya Samsul (2006) yang menyebutkan sebagai return aktual, yaitu return yang dihitung dengan cara membandingkan indeks hari ini dengan indeks hari sebelumnya. Indeks yang di maksud adalah indeks yang diperhitungkan setiap hari oleh manajer investasi berdasarkan nilai aset bersih (NAB), kinerja reksadana saham sangat diperlukan dengan menggunakan perhitungan dari setiap nilai aktiva bersihnya untuk mengukur dan melihat prospek kinerja reksadana saham tersebut setiap periode nya.

PT Mandiri Manajemen Investasi atau yang lebih dikenal sebagai Mandiri Investasi didirikan pada 26 Oktober 2004 setelah memisahkan diri (spin-off) dari PT Mandiri Sekuritas. Mandiri Investasi, yang merupakan bagian dari grup PT Bank Mandiri (Persero) Tbk, adalah manajer investasi nasional terbesar yang berpengalaman di bidang pengelolaan portofolio investasi sejak 1993, dengan nomor izin usaha MI: No. Kep-11/PM/MI/2004.

Produk dan layanan di dukung oleh pemahaman mendalam tentang situasi pasar di Indonesia, Mandiri Investasi akan membantu mengelola dana anda melalui produk investasi yang inovatif dan profesional, meliputi: a. Reksadana, Mandiri Investasi menghadirkan beragam produk-produk Investasi bagi anda seperti Reksadana Saham, Reksadana Campuran, Reksadana Pendapatan Tetap, Reksadana Pasar Uang, serta Reksadana Terproteksi. Setiap produk investasi dirancang secara khusus untuk memenuhi berbagai tingkat kebutuhan berinvestasi anda.

b. Investasi Alternatif, keahlian dan pengalaman pengelolaan investasi di Mandiri Investasi tidak hanya pada efek yang diperdagangkan di Bursa Efek Indonesia dalam bentuk Reksadana, namun juga menyediakan beragam solusi pendanaan dan Investasi Alternatif seperti Investasi langsung, structured finance dan infrastruktur melalui produk investasi seperti Kontrak Investasi Kolektif Efek Beragun Aset (KIK-EBA), Kontrak Investasi Kolektif Dana Infrastruktur (KIK-DINFRA), serta Reksadana Penyertaan Terbatas.

c. Pengeloalaan dana nasabah secara individual, Mandiri Investasi menawarkan jasa Pengelolaan Dana Nasabah Secara Individual (PDNI) yang dapat disesuaikan dengan kebutuhan investor, berdasarkan tujuan investasi dan profil risikonya.

Ada banyak jenis produk reksadana saham yang ditawarkan seperti Mandiri Global Sharia Equity Dollar (MGSED), Mandiri Investa Equity Dynamo Factor (DYNAMO), Mandiri Investa Ekuitas Dinamis (MIED), Mandiri Investa Ekuitas Syariah (MIES), Mandiri Investa Cerdas Bangsa (MICB), Mandiri Investa Equity ASEAN 5 Plus (ASEAN 5), Mandiri Investa Atraktif Syariah (MITRAS), dan Mandiri Investa Atraktif (MITRA). Dalam penelitian ini hanya berfokus dengan menggunakan salah satu produk investasi dari Mandiri Investasi berupa investasi Reksadana saham yaitu Mandiri Investa Atraktif (MITRA).

Berdasarkan uraian dalam latar belakang yang telah dikemukakan tersebut maka rumusan masalah dalam penelitian ini adalah:

1. Bagaimana perkembangan umur Reksadana Saham pada perusahan Mandiri Investasi periode 2014-2019?

2. Bagaimana perkembangan Expense Ratio Reksadana Saham pada perusahaan Mandiri Investasi periode 2014-2019?

3. Bagaimana perkembangan Nilai Aktiva Bersih (NAB) Kinerja Reksadana Saham 
pada perusahaan Mandiri Investasi

2014-2019?

\section{METODOLOGI PENELITIAN}

\section{Umur Reksadana}

Usia/ umur reksadana (fund age) adalah merupakan cerminan dari lamanya suatu reksadana telah dioperasikan yang dihitung sejak tanggal efektif reksadana mulai diperdagangkan. Semakin lama umur suatu reksadana maka akan semakin banyak pengalaman yang didapat dalam mengelola portofolio jika dibandingkan dengan reksadana yang baru atau berumur lebih muda serta pengalokasian arus kas sudah tertata lebih baik berikut juga portofolionya.

\section{Expense Ratio}

Expense Ratio adalah perbandingan biaya operasional reksadana dengan total dana yang dikelola. Biaya-biaya tersebut meliputi seluruh biaya operasional reksadana termasuk biaya manajemen dan biaya administratif. Sebagian besar biaya adalah biaya manajemen yang dibayarkan kepada perusahaan manajemen dana untuk jasa konsultasi. Biaya ini digunakan untuk membayar biaya yang terkait dengan portofolio, menyewa seorang fund manager, dan kompensasi untuk penelitian dan analisis yang dilakukan. Sehingga biaya yang dikeluarkan menghasilkan susunan portofolio terbaik yang dapat memberikan return yang maksimal sehingga dapat meningkatkan kinerja reksadana.

\section{Nilai Aktiva Bersih (NAB)}

Nilai aktiva bersih (NAB) adalah merupakan salah satu tolak ukur dalam memantau hasil dari suatu reksadana. NAB adalah total market value dari suatu portofolio dikurangi kewajibannya, dibagi dengan total jumlah saham yang beredar dan juga sejumlah aktiva setelah dikurangi kewajiban-kewajiban yang ada.

\section{METODE PENELITIAN}

\section{Locus}

Lokasi penelitian ini dilakukan diperusahaan Mandiri Investasi berdasarkan data publikasi reksadana saham atraktif periode 2014-2019, yang diambil malalui laman situs resmi Mandiri Investasi https://mandiri-investasi.co.id.

Objek
Variabel yang diteliti berupa umur reksadana, expense ratio dan kinerja reksadana (NAB).

\section{Sumber Data}

Sumber data yang dipergunakan dalam penelitian ini meliputi data sekunder yaitu data yang diperoleh melalui buku dan jurnal, yang dianggap menjadi referensi pendukung, berupa teori-teori dan informasi yang berkaitan dengan penelitian, peneliti mengambil berupa data sekunder berupa data laporan reksadana saham perusahaan yang terdapat di BEI, Bareksa, Pasardana dan Mandiri Investasi.

\section{Metode Pengumpulan Data}

Adapun metode pengumpulan data yang digunakan dalam penelitian ini adalah studi kepustakaan yaitu teknik pengumpulan data dengan mengadakan penelaahan terhadap buku-buku, literatur-literatur, catatan-catatan, dan laporan-laporan yang ada hubungannya dengan masalah yang dipecahkan.

\section{Metode Analisis Data}

Jenis metode dalam penelitian ini adalah analisis deskriptif, metode analisis deskriptif merupakan suatu metode yang berfungsi untuk mendeskripsikan atau memberi gambaran terhadap objek yang diteliti melalui data atau sampel yang telah terkumpul sebagaimana adanya tanpa melakukan analisis dan membuat kesimpulan yang berlaku untuk umum (Sugiono, 2009:29).

Langkah-langkah metode analisis 1. Menganalisis umur reksadana, dengan rumus:

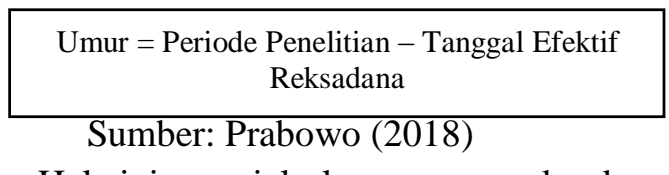

Hal ini menjelaskan umur reksadana memberikan bukti langsung bahwa ada hubungan positif antara usia dan reksadana, yang dapat dilihat dari periode penelitian dan tanggal efektif reksadana, yang menunjukkan adanya pengalaman ekonomi. Hal ini menyatakan bahwa analisis umur reksadana sangat berperan penting terhadap reksadana saham. 
2. Menganalisis expense ratio, dengan rumus:

$$
\text { Expense Ratio }=\frac{\left(\sum_{i=1}^{n} \frac{T B t}{A B t}\right)}{N}
$$

Sumber: Lidyah (2017)

Hal ini menjelaskan bahwa Expense ratio merupakan total biaya yang dikeluarkan untuk kegiatan operasional perusahaan yang meliputi biaya administrasi dan manajemen untuk menunjang operasional reksadana, hal ini yang menjadi bukti bahwa analisis expense ratio sangat berperan penting di dalam reksadana saham.
3. Menganalisis Kinerja reksadana Nilai Aktiva Bersih (NAB), dengan rumus:

$$
\mathrm{NAB}=\frac{\text { (Jumlah Aset-Total Kewajiban) }}{\text { Jumlah Unit Penyertaan }}
$$

Sumber: Iman (2008:128)

Hal ini menjelaskan bahwa nilai aktiva bersih (NAB) didalam reksadana saham sangat diperlukan dengan menggunakan perhitungan dari setiap nilai aktiva bersihnya untuk mengukur dan melihat prospek kinerja reksadana saham tersebut setiap periodenya, dilihat dari jumlah aset, total kewajiban dan jumlah unit penyertaannya. Hal ini yang menjadi bukti bahwa analisis nilai aktiva bersih (NAB) sangat diperlukan dalam reksadana saham.

\section{ANALISIS DAN PEMBAHASAN}

\section{Perkembangan Umur Reksadana Mandiri Investa Atraktif (MITRA) Pada Perusahaan Mandiri Investasi Periode 2014-2019}

Tabel 1. Umur Reksadana Saham Mandiri Investa Atraktif (MITRA) pada perusahaan Mandiri Investasi Periode 2014-2019

\begin{tabular}{ccc}
\hline $\begin{array}{c}\text { Periode } \\
\text { Penelitian }\end{array}$ & $\begin{array}{c}\text { Tanggal Efektif } \\
\text { Reksadana }\end{array}$ & Umur Reksadana \\
\hline 2014 & 2005 & $9 \mathrm{Thn}$ \\
2015 & 2005 & $10 \mathrm{Thn}$ \\
2016 & 2005 & $11 \mathrm{Thn}$ \\
2017 & 2005 & $12 \mathrm{Thn}$ \\
2018 & 2005 & $13 \mathrm{Thn}$ \\
2019 & 2005 & $14 \mathrm{Thn}$ \\
\hline
\end{tabular}

Sumber: Sumber: https://pasardana.id (data diolah)

Berdasarkan pada tabel 1. dapat dilihat bahwa perusahaan Mandiri Investasi pada periode penelitian 2014, sejak tanggal efektif reksadana saham Mandiri Investa Atraktif mulai diluncurkan pada tahun 2005 dan memperoleh umur reksadana yang berusia selama 9 tahun.

Pada periode penelitian tahun 2015, tanggal efektif reksadana saham Mandiri Investa Atraktif yang diluncurkan pada tahun 2005 sehingga memperoleh umur reksadana yang meningkat berusia 10 tahun.

Kemudian pada periode 2016 terhitung sejak tanggal efektif reksadana saham Mandiri Investa Atraktif diluncurkan pada tahun 2005 maka umur reksadana memperoleh usia 11 tahun.
Pada periode 2017 sejak tanggal efektif reksadana saham Mandiri Investa Atraktif diluncurkan sejak tahun 2005, maka memperpanjang umur reksadana saham menjadi berusia 12 tahun.

Begitu pula pada periode 2018 terhitung sejak tanggal efektif reksadana saham Mandiri Investa Atrakif diluncurkan pada tahun 2005 dan memperoleh umur reksadana yaitu 13 tahun.

Dan kemudian pada periode 2019 dan juga terhitung sejak tanggal efektif peluncuran reksadana saham Mandiri Investa Atraktif yakni pada tahun 2005, maka memperoleh umur reksadana saham yang berusia 14 tahun yang menunjukkan usia yang lama/panjang.

Dari hasil analisis umur reksadana saham Mandiri Investa Atrakrif pada perusahaan 
Mandiri Investasi periode 2014-2015, bahwa umur reksadana saham sejak tanggal efektif reksadana saham diluncurkan/diterbitkan pada tahun 2005 maka diperoleh umur reksadana/usia yang meningkat setiap periodenya, hal ini maka kita dapat melihat usia reksadana yang sudah berusia cukup lama/panjang dalam menjalankan reksadana sahamnya.

Menurut Rao (2000) mengatakan reksadana yang memiliki umur yang lebih lama akan memiliki track record yang lebih panjang, maka dari itu akan dapat memberikan gambaran kerja yang lebih baik kepada investornya. Oleh karena itu maka pada analisis umur reksadana saham Mandiri Investa Atraktif ini dapat memberikan gambaran kinerja yang menyatakan bahwa semakin tua umur reksadana maka ia akan berkinerja lebih baik, karena manajer investasinya sudah lebih berpengalaman dibandingkan dengan yang berusia muda.

\section{Perkembangan Expense Ratio Mandiri Investa Atraktif (MITRA) Pada Perusahaan Mandiri Investasi Periode 2014-2019}

Tabel 2. Expense Ratio Saham Mandiri Investa Atraktif (MITRA) pada perusahaan Mandiri Investasi Periode 2014-2019

\begin{tabular}{ccccccc}
\hline $\begin{array}{c}\text { Expense Ratio } \\
(\%)\end{array}$ & 2014 & 2015 & 2016 & 2017 & 2018 & 2019 \\
& 3,40 & 3,98 & 3,70 & 3,42 & 2,57 & 2,01 \\
\hline
\end{tabular}

Sumber:https://pasardana.id

Dari data tabel 2. tersebut maka diperoleh hasil data expense ratio reksadana saham Mandiri Investa Atrakrif per-periodenya yang telah tercatat pada laporan ikhtisar rasio keuangannya, yaitu pada tahun 2014 expense ratio diperoleh sebesar $3,40 \%$. Pada tahun 2015 mengalami kenaikan sebesar 3,98\%, pada tahun 2016 mengalami penurunan sebesar 3,70\%, pada tahun 2017 mengalami penurunan kembali sebesar 3,42\%, pada tahun 2018 mengalami penurunan yang cukup signifikan sebesar 2,57\% dan pada tahun 2019 mengalami penurunan yang cukup signifikan kembali sebesar $2,01 \%$, yang merupakan hasil dari perbandingan antara beban operasi dalam satu tahun dengan rata-rata nilai aset bersih dalam satu tahun.

Pada tahun 2014 tersebut diperolehnya nilai expense ratio sebesar $3,40 \%$, yang menunjukkan hasil yang menurun dari tahun sebelumnya, hal ini disebabkan dimana jumlah dari keuntungan investasi pada tahun tersebut juga mengalami penurunan dari tahun sebelumnya menjadi Rp 24.778.553.221, begitu juga jumlah beban investasi yang menurun juga dari tahun sebelumnya menjadi
Rp 15.146.308.542 yang menyebabkan pada beban operasi/ expense ratio menjadi turun, sehingga memberikan dampak yang kurang baik bagi perusahaan.

Kemudian pada tahun 2015 diperoleh nilai expense ratio nya sebesar $3,98 \%$, pada tahun tersebut megalami kenaikan dari tahun sebelumnya, hal ini disebabkan oleh keuntungan investasi mengalami kenaikan yang cukup signifikan menjadi sebesar $\mathrm{Rp}$ 40.447.999.684, jumlah unit penyertaan reksadana saham yang beredar menurun menjadi 60.280.233,6183 lembar, sehingga membuat jumlah beban investasi juga ikut menurun menjadi sebesar Rp 12.445.392.040 sehingga membuat biaya beban-beban investasi tidak terlalu banyak mengeluarkan biaya yang lebih, walaupun biaya operasi/ expense ratio meningkat, tetapi juga diimbangi dengan keuntungan investasi juga meningkat, hal ini memberi dampak yang positif bagi perusahaan.

Lalu pada tahun 2016 memperoleh nilai expense ratio sebesar $3,70 \%$, pada tahun tersebut mengalami penurunan dari tahun sebelumnya, tetapi tidak teralu signifikan dan masih relatif stabil, pada jumlah biaya beban investasi juga mengalami penurunan sebesar Rp 12.020.225.503. Dan pada keuntungan 
investasi juga mengalami penurunan menjadi sebesar Rp 24.657.225.578, sehingga membuat nilai expense ratio menurun, tetapi tidak terlalu signifikan dan tidak terlalu berdampak bagi perusahaan yang masih relatif stabil.

Pada tahun 2017 nilai expense ratio sebesar $3,42 \%$ ditahun ini expense ratio nya mengalami penurunan kembali, dilihat dari keuntungan investasi yang mengalami penurunan dari tahun sebelumnya menjadi sebesar Rp 17.428.307.167, tetapi jumlah unit penyertaaan reksadana saham yang beredar mengalami kenaikan menjadi 247.910.557,3839 lembar, dan jumlah beban investasi juga meningkat menjadi $\mathrm{Rp}$ 19.328.966.110, sehingga membuat biaya beban bertambah, akan tetapi keuntungan investasi yang diperoleh oleh perusahaan mengalami penurunan dari tahun sebelumnya, sehingga memberi dampak yang tidak cukup baik bagi perusahaan, walaupun biaya operasi/ expense ratio nya turun, tetapi keuntungan investasi perusahaan juga turun, hal ini berdampak tidak terlalu baik bagi perusahaan.

Pada tahun 2018 nilai expense ratio nya sebesar 2,57\% dapat dilihat pada tahun 2018 aktiva bersihnya mengalami penurunan dari tahun sebelumnya berjumlah Rp 4.673,7106 dan ditahun 2018 turun menjadi 4.619,2223, akan tetapi jumlah beban investasinya meningkat sebesar $\mathrm{Rp}$ 30.378.304.599, sehingga membuat biaya beban-beban investasi bertambah, keuntungan investasi perusahaan meningkat menjadi sebesar Rp 22.704.065.544, akan tetapi tidak diimbangi dengan jumlah unit penyertaan reksadana saham yang malah menurun. Hal ini berdampak positif bagi perusahaan karena dengan nilai biaya operasi/ expense ratio yang rendah, tetapi keuntungan investasi perusahaan meningkat.

Kemudian ditahun 2019 nilai expense ratio mengalami penurunan kembali menjadi sebesar 2,01\%, hal ini disebabkan karena jumlah beban investasinya mengalami penurunan menjadi sebesar Rp 25.426.662.929 dan aktiva bersihnya mengalami penurunan menjadi sebesar Rp 4.422,9464 sehingga membuat biaya beban-beban tidak terlalu banyak mengeluarkan biaya yang lebih, akan tetapi keuntungan investasi yang diperoleh perusahaan juga mengalami penurunan menjadi sebesar Rp 11.741.563.657, sehingga ini mengakibatkan dampak yang tidak begitu baik bagi perusahaan.

Dari hasil analisis tersebut, menurut See dan Jusoh dalam Kurniadi (2014) Expense ratio berpengaruh signifikan terhadap kinerja reksadana. Hal ini menjelaskan bahwa Expense ratio merupakan total biaya yang dikeluarkan untuk kegiatan operasional perusahaan yang meliputi biaya administrasi dan manajemen untuk menunjang operasional reksadana, yang telah tercantum didalam prospektus perusahaan atau didalam laporan ikhtisar keuangan perusahaan, hal ini yang menjadi bukti bahwa analisis expense ratio sangat berperan penting didalam reksadana saham Mandiri Investa Atraktif (MITRA) pada perusahaan Mandiri Investasi periode 2014-2019.

\section{Perkembangan Kinerja Reksadana Saham Yaitu Nilai Aktiva Bersih (NAB) Mandiri Investa Atraktif (MITRA) Pada Perusahaan Mandiri Investasi Periode 2014-2019.}

\section{Tabel 3. Kinerja Reksadana Saham (NAB) Mandiri Investa Atraktif (MITRA) \\ Pada Perusahaan Mandiri Investasi Periode 2014-2019 \\ (Disajikan Dalam Rupiah, Kecuali Dinyatakan Lain)}

\begin{tabular}{cccccc}
\hline Tahun & Jumlah Aset & Total Kewajiban & $\begin{array}{c}\text { Jumlah Unit } \\
\text { Penyertaan } \\
\text { (lembar) }\end{array}$ & $\begin{array}{c}\text { Nilai Aktiva } \\
\text { Bersih (NAB) }\end{array}$ & $\begin{array}{c}\text { Persentase } \\
\text { Perubahan } \\
\text { NAB }\end{array}$ \\
\hline 2014 & 609.906 .593 .604 & 16.614 .466 .766 & $137.327 .367,3249$ & $4.320,27$ & - \\
2015 & 236.029 .891 .334 & 8.171 .752 .063 & $60.280 .233,6183$ & $3.779,98$ & $-12,5 \%$ \\
2016 & 376.419 .580 .090 & 10.602 .626 .058 & $87.714 .580,1633$ & $4.170,53$ & $10,33 \%$ \\
2017 & 1.190 .078 .910 .355 & 31.416 .624 .120 & $247.910 .577,3839$ & $4.673,71$ & $12,06 \%$
\end{tabular}




$\begin{array}{llllll}2018 & 1.056 .546 .206 .851 & 6.669 .590 .857 & 227.284 .281,5040 & 4.619,22 & -1.16 \% \\ 2019 & 1.253 .544 .442 .859 & 3.564 .528 .607 & 282.612 .496,8433 & 4.422,94 & -4,24 \%\end{array}$

Sumber : https://pasardana.id (data diolah)

Pada tabel 3. dapat dilihat bahwa perkembangan nilai aktiva bersih (NAB) pada perkembangan reksadana saham pada perusahaan Mandiri Investasi pada tahun 2014 adalah sebesar $\mathrm{Rp} 4.320,27$ hasil yang didapatkan dari jumlah aset yang cukup besar pada tahun tersebut sebesar Rp 609.906.593.604 lalu dikurangkan dengan total kewajiban sebesar $\mathrm{Rp}$ 16.614.466.766 dan dibagi dengan jumlah unit penyertaaan reksadana saham sebesar 137.327.367,3249 lembar. Pada tahun tersebut dapat dilihat bahwa hasil dari perkembangan kinerja reksadana saham (NAB) nya cukup baik bagi perusahaan Mandiri Investasi.

Pada tahun 2015 mengalami penurunan yang cukup signifikan sebesar $\quad-12,5 \%$ yaitu Rp 3.779,98. Hal ini disebabkan oleh menurunnya jumlah aset sebesar $\mathrm{Rp}$ 236.029.891.334 dibanding tahun lalu, lalu di iringi juga menurunnya pada total kewajiban menjadi sebesar Rp 8.171.752.063 walaupun total kewajiban (hutang) relatif baik karena nilainya menurun pada tahun tersebut, akan tetapi setelah dibagi dengan jumlah unit penyertaan sebesar 60.280.233,6183 lembar, hasil dari aktiva bersih (NAB) nya juga menurun. Hal ini menjadikan dampak yang tidak baik bagi perusahaan karena berkurangnya juga nilai pendapatan bagi perusahaan Mandiri Investasi.

Pada tahun 2016 mengalami kenaikan kembali menjadi sebesar $10,33 \%$ yaitu $\mathrm{Rp}$ 4.170,53, hal ini disebabkan karena jumlah aset yang diperoleh juga meningkat sebesar Rp 376.419.580.090 begitu pula total kewajiban meningkat dari tahun sebelumnya menjadi sebesar Rp 10.602.626.058, dengan meningkatnya jumlah aset kewajiban yang dikurangkan dengan total kewajiban (hutang) lalu dibagi dengan jumlah unit penyertaan yang meningkat sebesar 87.714.580,1633 lembar. Dan hasilnya mendapatkan nilai aktiva bersih (NAB) yang juga meningkat. Hali ini menjadikan dampak yang baik bagi perusahaan karena meningkatnya kembali nilai aktiva bersih (NAB) perusahaan Mandiri Investasi tersebut.

Kemudian pada tahun 2017 nilai aktiva bersih (NAB) mengalami kenaikan yang cukup signifikan menjadi sebesar $12,06 \%$ yaitu $\mathrm{Rp}$ 4.673,71 hal ini disebabkan karena jumlah aset yang diperoleh pada tahun tersebut juga meningkat yang cukup signifikan sebesar Rp 1.190.078.910.355 dan diiringi kenaikan total kewajiban (hutang) yang besar yakni sebesar $\mathrm{Rp}$ 31.416.624.120, akan tetapi dimbangi dengan kenaikan pada jumlah unit penyertaan sebesar 247.910.577,3839 lembar, dan setelah dihitung mendapatkan angka nilai aktiva bersih (NAB) yang sangat meningkat dari tahun sebelumnya, hal ini menjadikan hal yang baik/positif bagi perusahaan Mandiri Investasi dalam menjalankan kinerja perusahaannya.

Namun pada tahun 2018 nilai aktiva bersih (NAB) mengalami penurunan sebesar $-1,16 \%$ menjadi Rp 4.619,22 yang diiringi jumlah aset perusahaan yang juga menurun sebesar $\mathrm{Rp}$ 1.056.546.206.851 dan begitu juga total kewajiban (hutang) yang juga menurun cukup signifikan sebesar $\mathrm{Rp}$ 6.669.590.857 yang justru memberi dampak positif bagi perusahaan karena hutang yang menurun, akan tetapi setelah dihitung dengan jumlah unit penyertaan yang juga menurun sebesar 227.284.281,5040 lembar dan mendapatkan hasil nilai aktiva bersih (NAB) nya juga menurun, tetapi masih relatif stabil yang tidak begitu terlalu berdampak negatif bagi perusahaan Mandiri Investasi karena masih dalam keadaan relatif stabil.

Dan pada tahun 2019 nilai aktiva bersih mengalami penurunan kembali menjadi sebesar $-4,24 \%$ yaitu $\mathrm{Rp}$ 4.422,94. Namun terjadi peningkatan pada jumlah aset perusahaan dari tahun sebelumnya menjadi sebesar Rp 1.253.544.442.859, lalu terjadi penurunan pada sektor total kewajibannya (hutang) perusahaan sebesar Rp 3.564.528.607 dan peningkatan pada jumlah unit penyertaan reksadana beredar

sebesar 282.612.496,8433 lembar. Maka diperoleh hasil nilai aktiva bersih (NAB) yang menurun kembali, yang disebabkan meningkatnya jumlah aset, walaupun total kewajiban menurun tetapi setelah dibagi dengan jumlah unit penyertaan yang malah justru meningkat, menghasilkan NAB yang masih tetap rendah/ turun, tetapi masih relatif stabil. Maka hal ini memberi dampak yang 
masih cukup relatif stabil bagi perusahaan Mandiri Investasi.

Dari analisis data tersebut maka nilai aktiva bersih (NAB) reksadana Mandiri Investa Atraktif (MITRA) pada perusahaan Mandiri Investasi periode tahun 2014-2019 mengalami hasil yang berbeda-beda setiap periodenya (fluktuatif) yang disebabkan oleh nilai jumlah aset, total kewajiban dan jumlah unit penyertaan yang berbeda-beda setiap tahunnya, yang tentunya menghasilkan nilai aktiva bersih (NAB) yang berbeda-beda setiap tahunnya.

Hal ini sejalan dengan teori penelitian menurut Iman (2008:128) nilai aktiva bersih (NAB) merupakan nilai pasar wajar (fair market value) suatu efek dan kekayaan lain dari reksadana yang dikurangi dengan kewajiban (utang). NAB merupakan salah satu tolak ukur dalam memantau hasil dari suatu reksadana. Kinerja reksadana saham sangat diperlukan dengan menggunakan perhitungan dari setiap nilai aktiva bersihnya untuk mengukur dan melihat prospek kinerja reksadana saham Mandiri Investa Atraktif (MITRA) perusahaan Mandiri Investasi tersebut pada setiap periodenya.

\section{KESIMPULAN DAN SARAN}

\section{Kesimpulan}

Berdasarkan hasil penelitian dan pembahasan yang telah dilakukan, maka dapat ditarik kesimpulan sebagai berikut:

1. Perkembangan umur reksadana saham Mandiri Investa Atraktf (MITRA) pada perusahaan Mandiri Investasi mengalami kenaikan usia pada tahun 2014-2019. Sedangkan perkembangan expense ratio pada tahun 2014-2019 mengalami penurunan. Dan pada perkembangan kinerja reksadana saham yakni nilai aktiva bersih (NAB) ditahun 2014-2019 mengalami fluktuasi.

2. Hasil penelitian ini menunjukkan variabel umur reksadana berusia sudah cukup relatif lama/panjang, hal ini dapat dilihat dari awal diterbitkannya reksadana saham Mandiri Investa Atraktif (MITRA) pada tahun 2005, lalu kemudian dilakukan awal penelitian ini mulai dari tahun 2014 dan mendapatkan umur reksadana saham yang berusia 9 tahun, ditahun 2015 berusia 10 tahun, ditahun 2016 berusia 11 tahun, tahun 2017 berusia 12 tahun, tahun 2018 berusia 13 tahun dan diakhir periode penelitian ini pada tahun 2019 umur reksadana saham Mandiri Investa Atraktif (MITRA) berusia 14 tahun. Maka dengan begitu dari periode 2014-2019 usia reksadana saham sudah berusia cukup lama yakni mencapai usia 14 tahun. Dengan demikian dapat disimpulkan bahwa umur reksadana saham Mandiri Investa Atraktif (MITRA) yang telah memiliki umur/usia reksadana saham yang sudah cukup lama/panjang, dapat memberikan gambaran kinerja yang baik bagi perusahaan Mandiri Investasi karena semakin tua umur reksadana maka ia akan berkinerja lebih baik, karena manajer investasinya sudah berpengalaman dibandingkan dengan yang berusia muda, dengan umur reksadana yang lebih muda mungkin akan menghadap pada biaya yang lebih tinggi pada periode awal.

3. Hasil penelitian ini menunjukkan variabel expense ratio reksadana saham Mandiri Investa Atraktif (MITRA) perusahaan Mandiri Investasi pada tahun 2014-2019 mengalami penurunan, namun pada masing-masing periode tersebut jumlah pendapatan/ keuntungan perusahaan masih relatif baik atau stabil dan masih bisa dapat menutupi biaya operasi perusahaan tersebut, hal lain juga bisa disebabkan karena dengan jumlah unit penyertaan reksadana saham yang tidak terlalu besar, maka beban-beban biaya operasional nya seperti biaya administrasi dan manajemen tidak terlalu banyak mengeluarkan biaya yang lebih untuk menunjang operasional reksadana, sehingga mengakibatkan turunnya nilai biaya operasi/ expense ratio pada setiap tahunnya. Hal ini dapat memberikan dampak yang baik bagi perusahaan karena biaya operasinya yang menurun menyebabkan biaya beban-beban yang dikeluarkan tidak terlalu besar pada perusahaan Mandiri Investasi.

4. Hasil penelitian ini menunjukkan variabel kinerja reksadana pada nilai aktiva bersih (NAB) reksadana saham Mandiri Investa Atraktif (MITRA) perushaaan Mandiri Investasi pada tahun 2014-2019 mengalami fluktuatif. Hal ini 
karena nilai aktiva bersih (NAB) pada setiap periodenya memiliki hasil yang berbeda-beda, ada yang meningkat dan ada pula yang menurun disetiap tahunnya. Maka dengan naik-turunnya (fluktuatif) hasil nilai aktiva bersih (NAB) reksadana saham Mandiri Investa Atraktif (MITRA) pada tahun 2014-2019, dapat mempengaruhi kinerja perusahaan Mandiri Investasi yang sangat diperlukan untuk mengukur dan melihat prospek kinerja reksadana saham Mandiri Investa Atraktif (MITRA) pada perusahaan Mandiri Saran Investasi tersebut setiap periodenya.

Berdasarkan penelitian dan pembahasan yang telah dilakukan, maka disarankan:

1. Bagi Investor

Bagi investor yang ingin memiliki atau akan menanamkan reksadana saham Mandiri Investa Atraktif (MITRA) pada perusahaan Mandiri Investasi, agar lebih memperhatikan umur reksadana, expense ratio dan kinerja reksadana saham pada nilai aktiva bersih (NAB) nya, sehingga investasi reksadana yang dilakukan bisa mendapatakan tingkat keuntungan yang diinginkan. Selain itu juga investor bisa melihat dan menilai tentang gambaran perusahaan tersebut dilihat dari kinerja perusahaan.

2. Bagi Perusahaan

Bagi perusahaan Mandiri Investasi agar diharapkan lebih memaksimalkan dan meningkatkan lagi reksadana saham Mandiri Investa Atraktif (MITRA) khususnya pada nilai expense ratio dan hasil aktiva bersih (NAB). Karena dengan lebih meningkatkan nilai aktiva bersih (NAB) nya, maka para investor akan melihat gambaran dan menilai kinerja perusahaan tersebut sudah baik dalam mengelola reksadana sahamnya. Sehingga para investor tidak ragu didalam menanamkan modalnya bagi perusahaan.

3. Bagi Peneliti Selanjutnya

Dalam melakukan penelitian diharapkan untuk menambah variabel-variabel lainnya dalam penelitian, seperti kinerja masa lalu (Past Performance), ukuran reksadana (Fund Size), arus kas reksadana (Fund Cash Flow), inflasi, dan Perubahan Portofolio (Turnover
Ratio), yang juga merupakan faktor lain terhadap kinerja reksadana saham.

\section{DAFTAR PUSTAKA}

Akbarini, M.D. 2004. Analisis Atas Pengaruh Nilai Aktiva Bersih, Umur Reksadana, Analisis dan Spesialisasi Manajer Investasi Terhadap Kinerja Reksadana penelitian empiris periode tahun 1999-2003. Tesis Pascasarjana Fakultas Ekonomi.Depok: Universitas Indonesia.

Asriwahyuni, I Gusti, Ayu, Prima. 2017. Pengaruh Ukuran dan Umur pada Kinerja Reksadana Saham Di Indonesia. Jurnal Akuntansi. Vol.21.2.ISSN: 2302-8556. Bali: Universitas Udayana.

Bitomo, Habib. 2016. Analisis Faktor-faktor yang mempengaruhi Kinerja Reksadana di Indonesia. Jurnal Manajemen Fakultas Ekonomika dan Bisnis. Vol 5. Nomor 2. ISSN:2337-3792. Semarang: Universitas Diponegoro.

Black, D dan Timmerman A. 1998. The Birth and Death Processes Of Mutual Fund. European Finance Riview. Vol 2, PP. 57-77.

Desiyanti, Rika. 2014. Persistensi Dan Konsistensi Kinerja Reksadana Di Indonesia. Jurnal Manajemen Bisnis. Vol.3. No.1 Padang: Universitas Bung Hatta.

Fahmi, Irham. 2018. Manajemen Investasi: Cetakan Kedua. Jakarta: Salemba empat.

Fahmi, Irham dan Yovi Lavianti Hadi. 2009. Teori Portofolio Dan Analisis Investas. Bandung: Alfabeta.

Kurniadi, D. 2014. Analisis Fund Size, Expense Ratio, Turnover Ratio, Fund Age dan Cash Flow Terhadap Kinerja Reksadana Saham di Indonesia periode 2010-2012. Skripsi Fakultas Ekonomika dan Bisnis. Semarang: Universitas Diponegoro.

Lidyah, Rika. 2017. Pengaruh Total Aset, Expense Ratio, dan Portofolio Turnover Terhadap Kinerja Reksadana Saham di Indonesia. Jurnal Manajemen Fakultas Ekonomi.Palembang: UIN Raden Fatah.

Meilinda, 2010. Reksadana Sebagai Salah Satu Alternatif Investasi. Jurnal Bina Ekonomi Majalah llmiah Fakultas Ekonomi. Vol.14. No.1. Bandung: Universitas Katolik Parahyangan.

Mudjiyono, 2012. Investasi dalam saham \& Obligasi dan Meminimalisasi Risiko 
Sekuritas Pada Pasar Modal Indonesia. Jurnal Manajemen Fakultas Ekonomi. Vol.4. No.2 (ISSN : 2252-7826). Semarang: STIE Semarang.

Nofie, Iman. 2008. Panduan Singkat dan Praktis Memulai Investasi Reksadana. Jakarta: PT. Gramedia.

Prabowo, Eko Bartadi. Analisis Pengaruh Expense Ratio, Market Timing Ability, Fund Age, Fund Size, Dan Fund Cash Flow Terhadap Kinerja Reksadana Saham. Jurnal Manajemen Fakultas Ekonomi. Yogyakarta: 2014

Rao, 2000. Market Timing and Mutual Fund Performance. Jurnal Bisnis. Vol.73 No.1 Hal: 75-79.

Samsul, Muhamad. 2006. Pasar Modal Dan Manajemen Portofolio.Surabaya: Erlangga.

Saurahman, 2015. Analisis Pengaruh Pemilihan Sekuritas, Market Timing, Tingkat Risiko, Umur Reksadana dan Ukuran Reksadana Terhadap Kinerja Reksadana campuran berbentuk kontrak investasi kolektif. Skripsi. Jakarta: UIN Syarif Hidayahtullah.

Sugiyono, 2009. Metode Penelitian Kuantitatif, Kualitatif dan $R \& D$. Bandung: Alfabeta.

Sugiyono, 2015. Metode Penelitian Kombinasi (Mix Methods). Bandung: Alfabeta.

Trisnopati, Titik Farida. 2015. Pengaruh Stock Slection, Market Timing, dan ukuran Reksadana Terhadap Kinerja Reksadana Saham. Jurnal e-proceeding of management. Vol 2(3). 3491-3497.

Usman, Marzuki. 2000. Bunga Rampai Reksa Dana. Jakarta:Balai Pustaka.

Waridah, Winda dan Mediawati, Elis. 2016. Analisis Kinerja Reksadana Syariah. (ISSN:2541-061X). (ISSN:2338-1507). Jurnal Riset Akuntansi Dan Keuangan. Bandung: Universitas Pendidikan Indonesia.

https://www.bareksa.com/id/

https://www.idx.co.id/

https://www.mandiri-investasi.co.id/

https://www.docplayer.info

https://www.pasardana.id/ 